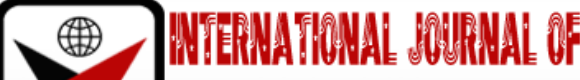 \\ בmRक
}

ISSN 2278-0211 (Online)

\section{Comparative Analysis of Cocoyam Varieties on Yield under Irrigation in Kano State, Nigeria}

\author{
Abu Mohammed \\ Principal Researcher, Department of Agricultural Education, School of Secondary \\ Education-Vocational, Federal College of Education, Nigeria \\ Abdulwahab I. Harbau \\ Co-Researcher, Department of Agricultural Education, School of Secondary Education- \\ Vocational, Federal College of Education, Nigeria
}

\begin{abstract}
:
This study was carried out to compare the growth rate and yield of Xanthosomasagittaifolium and Colocasiaesculenta cultivated under irrigation with NPK 15:15:15 fertilizer application at the rates of (100kg) and cow dung at the rate of 20t/ha respectively at two different locations. This was aimed at identifying growth rate and tuber yield potentials of the cocoyam cultivars on different experimental condition. The two locations used for the study were the Agricultural Education Research Farm; Federal College of Education (Tech) Bichi and Watari Irrigation Scheme site along Bichi-Bagwai and Gwarzo road. The two cultivars cultivated were replicated at both sites. The result showed that application of NPK 15:15:15 fertilizer increased growth rate (height and leaf size) of Xanthosomasagittaifolium with a mean value of 39.66 and 31.94, while the tuber yield has a mean value of 2.23 at Watarilrrigation Scheme respectively. Also, Colocasiaesculenta cultivated at Agricultural Education Research Farm with organic manure application has a higher tuber yield mean value of 1.98 than those at Watarilrrigation Scheme. The highest tuber yield of Xanthosomasagittaifolium was realized in response to the application of $100 \mathrm{~kg} / \mathrm{ha} N P K$ fertilizer application. Further increases above these rates in the locations caused non-significant decline in tuber yield. However, Colocasiaesculentacultivated at Imane (Major Producing Area) with organic manure application yielded better than those cultivated at WatariIrrigation Scheme with organic manure application under irrigation. The study concluded that both Xanthosomasagittaifolium and Colocasiaesculenta can be cultivated under irrigation. It was recommended that these cocoyam cultivars should be made available to farmers for trial and subsequent adoption through collaboration with extension agents. This will on the long run contribute to enhance and promote food security in Kano State and Nigeria at large.
\end{abstract}

Keywords: Xanthosomasagittaifolium, colocasiaesculenta, fertilizer, organic manure and tuber yield

\section{Introduction}

Cocoyam is an herbaceous perennial plant belonging to the family Araceae. It is grown primarily for its edible roots. It is an annual tropical plant primarily grown as a root and leafy vegetable crop for its edible starchy corm and leaf. Cocoyam according to Chukwu, (2015), is an important carbohydrate staple food, particularly in the southern and middle belt areas of Nigeria where they are highly valued and cherished by the people. Food and Agricultural Organization (FAO, 2006) explained that cocoyam is an annual crop used as food in most parts of the world especially in Asia and Nigeria.

Cocoyam has two major varieties, the first being Xanthosomasagitifolium which is mainly referred to as tannia. It originated from Central and South America and spread to other parts of the world. The second Colocasiaesculenta also referred to as taro originated from India and spread to Egypt and Nigeria. Nutritionally, cocoyam, according to Amusa, Enete and Okon (2011), is superior to cassava and yam in its possession of higher protein, mineral and vitamin contents in addition to having more digestible starch. Food and Agricultural Organization (FAO 2006) stated that millions of people depend on cocoyam in Africa, Asia and Latin America as it is the third most important sources of calories after rice and yam. International Institute for Tropical Agriculture (IITA) (2007) reported that cocoyam is an important food crop which when consumed supplies the body with protein and carbohydrates.

In Nigeria, the bulk of cocoyam produced is consumed as food, either as a primary product (corm, cormel, leaves and inflorescence) or as a secondary product (flour, cake, crisp, and chip). Nwabuzor (2001) and Asadu, (2006) noted that cocoyam can be consumed in various forms: boiled, fried, pounded or roasted and can also be processed into chips which have a long shelf and provide food all year round especially during lean planting season. Its leaves are also used as vegetable for preparing soup in various parts of the world. Cocoyam is highly cultivated in Nigeria especially in the south and some part of the middle belt. The average production figure in Nigeria according to Abdulrahman, Abdullahi and Muhammad (2015), is about 5,068,000 mt which accounts for about $37 \%$ of total world output. It has high economic 
potential, not only as food (main meal, snacks and adjunct in thickening soup) but also as an agro-industrial raw material for pharmaceutical, confectionery and livestock industries.Root and tuber crop production, according to Chukwu (2015), has significantly moved from the forest to savanna ecosystems which is evident in the expansion of yam cultivation into the savanna region that has become the new major growing area in West Africa. This is due to agronomic and ecological factors such as temperature, higher soil fertility and moisture availability. Similarly, total annual precipitation in these areas ranged from $400-1,000 \mathrm{~mm}$. This amount of rainfall (precipitation) may not sustain cocoyam production without irrigation. Consequently, it is expected that with the expansion of root crop belt northwards, where soil moisture is $\geq 1,500$ $\mathrm{KPa}$ tension, at least for 90 days out of expected 180 - 240 days, the moisture content may not sustain its growth to maturity hence the need to supplement through irrigation.

Irrigation is very essential in crop production especially in areas where there is insufficient rainfall. Irrigation, according to Adelekan (2006), is the artificial application of water to the soil in order to enhance the growth and development of crops. It is the process by which water is brought to land through any of the variety of artificial means. Sometimes the reason for irrigating a portion of land is that it happens to be a dry season with less than average amount of rainfall, while other times, it is necessary to do so because that land would never receive enough water on its own to be fertile. Siryater, et'al (2005) emphasized that irrigation assist in the growing of agricultural crops, maintenance of landscape and re-vegetation of distributed soil in dry area and during period of inadequate rainfall. Additionally, irrigation has other uses in crop production which include cooling of soil temperature, improving water infiltration into the soil, dissolution of available plant food in the soil for the use of plants.

The amount of water, according to Adelekan (2006), that is to be used for irrigation is dependent on the type of crop that is being farmed as well as the amount of rainfall associated with the climate of the region where the farm is located. Food and Agricultural Organization (FAO, 2006) explained that in the United States, about one third of the total amount of water that is used each year is utilized for the purpose of irrigation. It is usually used to cultivate food crops such as maize, potatoes among others. However, despite the availability of irrigation facility and the challenge of food shortage in the country, the advantage of cocoyam cultivation is not yet exploited in northern Nigeria.

Currently, cocoyam is highly produced in the southern part of the country. This region has high rainfall of about 1517 to $1799 \mathrm{~mm}$ (Ngene, et' al, 2018). However, the region lacks adequate field to cultivate the large quantity required for food security. Therefore, cocoyam as a staple food crop could be cultivated under irrigation in Kano State. Many farmers in the State are involved in the cultivation of vegetables such as ammaranthus, tomato, onions, cabbage among others under irrigation. These groups of farmers can integrate cocoyam production in their vegetable production plan with a view to boosting and increasing its production which could also serve as alternative or substitute for yam supply in the state. However, in other Northern states where there is vast land for the cultivation of the crop to commercial quantity; there is no adequate rainfall to match the water needs of the crop. Kano state is one of the states in Nigeria with the largest irrigation sites. Sangari (2006) reported that the State has an estimated irrigation land of 62,000 hectares. The irrigation site provides possible environment for the production of the crop. This has not been experimented. This study therefore, determined the potentiality of cultivating cocoyam (varieties) on irrigated land in Kano State. The study will also determine which of the species perform better in Kano State and its environs.

\subsection{Statement of Problem}

Cocoyam as a staple food crop is highly consumed in Nigeria, Asia and part of Europe, but its level of production in the view of Nenna, Ugwumba, Obiekwe and Akubuilo, (2017), is grossly inadequate to meet its demand. In Nigeria for instance, cocoyam is mostly produced in the South East, South West and part of North Central state, particularly Kogi and Benue States. Production of cocoyam in these parts of the country is purely based on rain fed system as it requires adequate water supply for its growth and development. Cocoyam production in South Eastern Nigeria is threatened by inadequacy of land for its cultivation. Conversely, in the North where there is vast arable land, the rainfall is too small to support the cultivation. However, the Northern Nigeria especially Kano State has large area of irrigated land that could sustain cocoyam production. This assumption calls for trial of cocoyam production in Kano State.

\subsection{Significance of the Study}

The study is of significant value to the people of Kano State and the nation at large as it experimented the viability of cocoyam production in Kano State. Its success would help in improving food security. It could improve the utilization of irrigation facilities in Kano State and its environs for crop production. It would also create employment opportunities for the youths in the area of production, processing and marketing of the products. The skills developed from the experimentation could also be integrated into crop production course contents of schools and colleges for implementation.

\subsection{Purpose of the Study}

The major purpose of the study was to grow cocoyam varieties under irrigation and different experimental conditions and determine the yield potentials in Kano State. Nigeria. Specifically, the study sought to:

- Determine the viability of cocoyam production under irrigation in Kano State.

- Compare the tuber yield of Xanthosomasagitaifolium and Colocasiaesculenta produced under irrigation.

- Compare the tuber yield of Xanthosomasagitaifolium and Colocasiaesculenta produced under irrigation and yield from a major producing area (Imane) in Kogi State.

\subsection{Research Questions}

The study was guided by the following research questions 
- What is the difference in growth rate (plant height) of Xanthosomasagitaifolium and Colocasiaesculenta produced under irrigation?

- What is the difference in growth rate (Leaf size) of Xanthosomasagitaifolium and Colocasiaesculenta produced under irrigation?

- What is the difference in tuber yield between Xanthosomasagitaifolium and Colocasiaesculenta cultivated under irrigation and yield from a major producing area (Imane) in Kogi State?

\subsection{Research Hypothesis}

- Ho1 There is no significant difference in the mean ratings of the growth rate (plant height) of Xanthosomasagitaifolium and Colocasiaesculenta cultivated under irrigation in Kano State.

- Ho2 There is no significant difference in the mean ratings of the growth rate (leaf size) of Xanthosomasagitaifolium and Colocasiaesculenta cultivated under irrigation in Kano State.

- Ho 3 There is no significant difference in the mean ratings of the tuber yield between Xanthosomasagitaifolium and Colocasiaesculenta cultivated under irrigation in Kano State and those cultivated in a Major Producing Area (Imane) in Kogi State.

\subsection{Research Design}

The study adopted Factorial Experimental Design in a randomized complete block design (RCBD). The study was carried out in two locations; Agricultural Education Research Farm and Watari Irrigation Scheme Site. The procedure that was used in the study has treatments for both groups that were randomized. Both varieties of cocoyam Xanthosomasagitaifolium and Colocasiaesculenta were grown on $50 \times 501 / 2$ ha area of land at both sites. The two (2) setups were captured experimental groups and replicate while cocoyam conventionally cultivated at Imane (major producing area) in Kogi State served as control. The treatments consisted of the two cocoyam cultivars (Xanthosomasagitaifolium and Colocasiaesculenta), Fertilizer (NPK 15:15:15) at the rate of $100 \mathrm{~kg} / \mathrm{ha}$ and organic manure at the rate of twenty (20) t/ha. There were eight (8) treatments each with sixteen (16) replicates. Planting was done immediately after land preparation at the depth of $10 \mathrm{~cm}$ and at the spacing of $35 \times 95 \mathrm{~cm}$. Weeding was done manually twice at 6 and 16 weeks after planting. At maturity, harvesting was also done manually. After the treatment, the growth rate and yield from the two groups were compared.

\subsection{Area of the Study}

The study was carried out at the Agricultural Education Research Farm; Federal College of Education (Tech) Bichi located along old Bagwai road Bichi and Watari Irrigation Scheme Site, Kano State. The soil textural class is sandy loam. The WatariIrrigation Scheme Site is situated along Bichi - Gwarzo road, North-Western part of Kano about $50 \mathrm{~km}$ from Kano city. Shanono, et'al (2015) stated that theWatari Irrigation Scheme Site is located within latitude $12^{\circ} 6^{\prime}-12^{\circ} 10^{\prime} \mathrm{N}$, and longitude $8^{\circ} 09^{\prime}-8^{\circ} 16^{\prime} \mathrm{E}$. Adam (2013) also observed that the area has altitude of about $490 \mathrm{~m}$ in a valley of the Watari River within Sudan and Guinea Savanna agro-ecological zones with a total land area of 457 ha. Kano State has a warm climate with an average annual rainfall of $800 \mathrm{~mm}$ and has an average temperature of $26^{\circ \mathrm{C}}$ which is slightly suitable for cocoyam production. The soil according to Dawakiet'al, (2013) is slightly alkaline and within the pH range of 5.3 to 7.48, CEC- moderate (12.63), Organic carbon -medium $(11.27 \mathrm{~g} / \mathrm{kg})$ and the mean range of total $\mathrm{Cu}, \mathrm{Cr}, \mathrm{Ni}, \mathrm{Zn}, \mathrm{Pb}$, and $\mathrm{Cd}$ were lower than the maximum allowable concentration in soil which makes it adaptable to growing of cocoyam. Both locations were used as experimental sites for the study.

\subsection{Data Collection and Analysis}

The data for the study was collected by measuring plant heights and leaf width in centimeters (cm) at an interval of two weeks after planting. The mean of the maximum height and leaf size obtained at maturity were used. Also, weighing balance was utilized in obtaining yield weight per unit across samples of selected plants after harvesting. The average of total yield/stand was calculated. The data generated was analyzed using Mean to answer the research questions and Analysis of Variance (ANOVA) was used for comparing performance in terms of growth and tuber yield. Significant means were separated using Scheffes Multiple Comparison and Homogenous Sub Set Test at probability level of 0.05.

\section{Results}

\subsection{Research Question 1}

What is the difference in growth rate (plant height) of Xanthosomasagitaifolium and Colocasiaesculenta produced under irrigation?

\subsubsection{Hypotheses 1}

Ho 1 , There is no significant difference in the mean ratings of the growth rate (plant height) of Xanthosomasagitaifolium and Colocasiaesculenta cultivated under irrigation in Kano State. 


\begin{tabular}{|c|c|c|c|c|c|}
\hline & Sum of Squares & df & Mean Square & F & Sig. \\
\hline Between Groups & 12435.657 & 7 & 1776.522 & 145.500 & 0.001 \\
Within Groups & 5762.999 & 472 & 12.210 & & \\
Total & 18198.656 & 479 & & & \\
\hline
\end{tabular}

Table 1: Analysis of Variance (ANOVA) on the Growth Rate (plant height) of

Xanthosomasagitaifolium and Colocasiaesculenta Cultivated at the Two (2) Experimental Sites

Table $(1 \mathrm{a}) \mathrm{F}(7,472)=145.500 \mathrm{P}<0.05$ revealed that there is a significant difference in the height of the 2 experimental species under the experimental condition. The null hypothesis is rejected. To find the point of difference, the data was further subjected to Scheffe's multiple comparison and homogenous sub set test as shown below:

\begin{tabular}{|c|c|c|c|c|c|c|}
\hline \multirow{2}{*}{ TREATMENT } & \multirow{2}{*}{$\mathbf{N}$} & \multicolumn{5}{|c|}{ Subset for alpha $\mathbf{0 . 0 5}$} \\
\cline { 3 - 7 } & & $\mathbf{1}$ & $\mathbf{2}$ & $\mathbf{3}$ & $\mathbf{4}$ & $\mathbf{5}$ \\
\hline AGB2CHO & 60 & 21.6687 & & & & \\
\hline WTB2CHO & 60 & & 25.5327 & & & \\
\hline AGB1CHF & 60 & & & 28.0753 & & \\
\hline AGA2XHO & 60 & & & 28.1192 & & \\
\hline WTA2XHO & 60 & & & & 31.8340 & \\
\hline WTB1CHF & 60 & & & & 31.9463 & \\
\hline AGA1XHF & 60 & & & & 33.1765 & \\
\hline WTA1XHF & 60 & & & & & 39.6648 \\
\hline Sig. & & 1.000 & 1.000 & 1.000 & .729 & 1.000 \\
\hline
\end{tabular}

Table 2: Homogeneous Subsets

Means for Groups in Homogeneous Subsets Are Displayed

The Scheff's test of homogeneity (Table 1b) grouped the means into homogenous subsets based on the proximity of the values. Subsets 1 and 2 revealed that Colocasiaesculenta (AGB2CHO) cultivated at Agricultural Education Research Farm with organic manure application performed least in terms of height than those cultivated at Watari Irrigation Scheme Site and are significantly different from one another. Subset 3, 4 and 5 showed that there was significant difference in favour of Xanthosomasagitaifolium (WTA1XHF) in experimental groups (A) cultivated with fertilizer application at Watari Irrigation Scheme Site having the highest performance in terms of height.

\subsection{Research Question 2}

What is the difference in growth rate (Leaf size) of Xanthosomasagitaifolium and Colocasiaesculenta produced under irrigation?

\subsubsection{Hypotheses 2}

- $\mathrm{Ho}^{2}$, There is no significant difference in the mean ratings of the growth rate (leaf size) of Xanthosomasagitaifolium and Colocasiaesculenta cultivated under irrigation in Kano State.

\begin{tabular}{|c|c|c|c|c|c|}
\hline & Sum of Squares & df & Mean Square & F & Sig. \\
\hline Between Groups & 17685.435 & 7 & 2526.491 & 246.770 & 0.001 \\
Within Groups & 4832.451 & 472 & 10.238 & & \\
Total & 22517.886 & 479 & & & \\
\hline
\end{tabular}

Table 3: Analysis of Variance (ANOVA) on the Growth Rate (Leaf Size) of Xanthosomasagitaifolium and Colocasiaesculenta Cultivated at the Two (2) Experimental Sites

Also, table (3) F $(7,472)=246.770 \mathrm{P}<0.05$ showed that there is a significant difference in the leaf size of the two (2) experimental groups under the experimental condition. Therefore, the null hypothesis is rejected. To trace the point of difference, the data was further subjected to Scheffe's multiple comparison and homogenous sub set test. The summary of the analysis is presented in Table $2 \mathrm{~b}$ as shown below:

\begin{tabular}{|c|c|c|c|c|c|}
\hline \multirow[t]{2}{*}{ Treatment } & \multirow[t]{2}{*}{$\mathbf{N}$} & \multicolumn{4}{|c|}{ Subset for alpha $=0.05$} \\
\hline & & 1 & 2 & 3 & 4 \\
\hline AGB2CHO & 60 & 16.8718 & & & \\
\hline AGA2XHO & 60 & 17.0973 & & & \\
\hline WTB2CHO & 60 & & 22.6103 & & \\
\hline AGB1CHF & 60 & & 23.8845 & & \\
\hline WTB1CHF & 60 & & & 29.4608 & \\
\hline AGA1XHF & 60 & & & 29.4848 & \\
\hline WTA2XHO & 60 & & & 30.2432 & \\
\hline WTA1XHF & 60 & & & & 34.7032 \\
\hline Sig. & & 1.000 & .689 & .970 & 1.000 \\
\hline
\end{tabular}

Table 4: Homogeneous Subsets 
The Scheffe's test of homogeneity (Table $2 \mathrm{~b}$ ) grouped the means into homogenous subsets based on the proximity of the values. Subsets 1 and 2 revealed that Colocasiaesculenta (AGB2CHO) cultivated at Agricultural Education Research Farm with organic manure application performed least in terms of leaf size than those cultivated at Watari Irrigation Scheme Site and are significantly different from one another. Subset 3 and 4 showed that there was a significant difference in favour of Xanthosomasagitaifolium (WTA1XHF) in the experimental groups (A) cultivated with fertilizer application at Watari Irrigation Scheme Site having the highest performance in terms of leaf size.

\subsection{Research Question 3}

What is the difference in tuber yield between Xanthosomasagitaifolium and Colocasiaesculenta cultivated under different experimental conditions?

\subsubsection{Hypotheses 3}

Ho2, There is no significant difference in the mean ratings of the tuber yield between Xanthosomasagitaifolium and Colocasiaesculenta cultivated under irrigation in Kano State

\begin{tabular}{|c|c|c|c|c|c|}
\hline & Sum of Squares & df & Mean Square & F & Sig. \\
\hline Between Groups & 53.524 & 7 & 7.646 & 43.880 & 0.001 \\
Within Groups & 82.248 & 472 & & & \\
Total & 135.772 & 479 & .174 & & \\
\hline
\end{tabular}

Table 5: Analysis of Variance (ANOVA) on Yield Performance of Xanthosomasagitaifolium and Colocasiaesculenta Cultivated at the Two (2) Experimental Sites and Major Producing Area

Table $5 \mathrm{~F}(7,472)=43.880 \mathrm{P}<0.05$ revealed that there is a significant difference in the yield of the two (2) experimental species under the experimental condition. Therefore, the null hypothesis of no significant difference is rejected. To ascertain the point of difference, the data was further subjected to Scheffe's multiple comparison and homogenous sub set test in Table 6 as shown below:

\begin{tabular}{|c|c|c|c|c|c|}
\hline TREATMENT & \multirow{2}{*}{$\mathrm{N}$} & \multicolumn{4}{|c|}{ Subset for alpha $=0.05$} \\
\cline { 3 - 6 } & & 1 & 2 & 3 & 4 \\
\hline AGB2CHO & 60 & 1.0467 & & & \\
\hline WTB2CHO & 60 & & 1.4663 & & \\
\hline AGB1CHF & 60 & & 1.4893 & & \\
\hline AGA2XHO & 60 & & 1.5598 & & \\
\hline WTA2XHO & 60 & & 1.6238 & & \\
\hline AGA1XHF & 60 & & 1.6548 & 1.6548 & \\
\hline WTB1CHF & 60 & & & 1.9878 & 1.9878 \\
\hline MPAYC & 60 & & & & 2.0692 \\
\hline MPAYX & 60 & & & & 2.1350 \\
\hline WTA1XHF & 60 & & & & 2.2397 \\
\hline Sig. & & 1.000 & .839 & .083 & .457 \\
\hline
\end{tabular}

Table 6: Homogeneous Subsets

Means for Groups in Homogeneous Subsets Are Displayed

The Scheffe's test of homogeneity (Table 6) grouped the means into homogenous subsets based on the proximity of the means. Subsets 1 revealed that Colocasiaesculenta (AGB2CHO) cultivated at Agricultural Education Research Farm with organic manure application performed least in terms of tuber yield than those cultivated at Watari Irrigation Scheme. Subset 2 showed that no significant difference in the tuber yield of Colocasiaesculenta cultivated with fertilizer application at Agricultural Education Research Farm and at Watari Irrigation Scheme Site. Subset 4 revealed that Colocasiaesculenta (WTB2CHO) has least tuber yield performance in comparison with Colocasiaesculenta (MPAYC) from the major producing area. But Xanthosomasagitaifolium (WTA1XHF) cultivated at Watari Irrigation Scheme Site performed higher in terms of tuber yield than Xanthosomasagitaifolium (MPAYX) from the major producing area. This showed that there was no significant difference in the yield of Xanthosomasagitaifolium produced under irrigation and that of the major producing area.

\section{Discussion of Results}

The study revealed higher level of viability of cocoyam cultivated at both Watari Irrigation Scheme Site and Agricultural Education Research Farm. Xanthosomasagitaifolium cultivated at Watari Irrigation Scheme Site with fertilizer application has high viability and growth rate than those planted at Agricultural Education Research farm, whileColocasiaesculenta cultivated with organic manure atAgricultural Education Research farmalso has high viability and growth rate than those planted at Watari Irrigation Scheme Site. These observations are supported with the research findings which revealed that Xanthosomasagitaifolium growth rate (height and leave size) cultivated with NPK 15:15:15 fertilizer application is higher with a mean value of 39.66 and 31.94 than that ofColocasiaesculenta cultivated with organic 
manure application with a mean value of 30.24 and 29.46respectively. These findingsaredue to the good growth rate showed by the plants.

The yield compared to other producing areas like Nsukka and Umudike as reported by Ogbonna and Nweze (2012), which state that application of NPK15:15:15 fertilizer increased growth rate in cocoyam. However, the highest tuber yield/ha of 37.85 tons/ha atNsukka and 20.845 tons/ha at Umudike were attained in response to the application of 200 and $250 \mathrm{~kg} / \mathrm{ha}$, respectively. The finding of the study is also in line with the finding of Mare and Modi, (2009) which state that the significant effect caused by application of NPK 15:15:15 fertilizer to the growth and tuber yield of Xanthosomasagitaifolium plots showed that soil in these areas lacked essential nutrients, especially those that enhance growth and development in cocoyam. Also, Mary, Dominic and Cosmos (2017) observed that cocoyam production in South Eastern, Nigeria is usually without any application of manure or fertilizer. The plant itself seeks for the nutrients as it is a heavy feeder. Hence this opportunity enables the plant to perform well in all land conditions.

The addition of manure and fertilizer in the present study provides the plant adequate nutrients to grow well. Mary, Dominic and Cosmos (2017), reported that organic manure improves cocoyam growth and yield performance. Similarly, Ogbonna and Nweze (2012), reported that application of fertilizer increased the growth of cocoyam. The study also revealed that different cultivars (species) respond differently to the present study in which Xanthosomasagitaifolium outgrew Colocasiaesculenta. This is supported by the result of the physicochemical properties of the soils of the sites prior to the establishment of the experiments as reported byDawaki, et'al, (2013).

These results further indicated that cultivatingXanthosomasagitaifolium with NPK 15:15:15 Fertilizer application under irrigation can yield better than without fertilizer in the experimental area.However,Colocasiaesculentacultivated at Imane with organic manure application yielded better thanColocasiaesculentacultivated at Watari Irrigation Scheme with organic manure application under irrigation. The result of this study is also in linewith the findings of Mary, Dominic and Cosmos, (2017) which revealed that cocoyam growth and yield increased significantly $(P=0.05)$ with increased application ofcow dung up to $20 \mathrm{t} /$ ha when the soil had $0.03 \% \mathrm{~N}$ and $0.65 \% \mathrm{OM}$, but not beyond the rateof $10 \mathrm{t} / \mathrm{ha}$ when the soil had $0.06 \% \mathrm{~N}$ and $1.22 \% \mathrm{OM}$. The disparities in response to the application of the organic manure may be related to such factors as soil nutrient, moisture status as well as weather factors. This study showed that both NPK 15:15:15 fertilizer and organic manure application improved growth and yield of cocoyam with NPK 15:15:15 fertilizer application having a better performance than cow dung.

Another important finding is the significant difference between the two experimental species in WatariIrrigation Scheme and Agricultural Education Research Farm. The study revealed that the cultivars showed significant differences in terms of yield. This could be due to the water availability difference between the two experimental sites. The Watari Irrigation Schemesite had better water availability.Similarly,the Watari Irrigation Schemesite has more clay loam soil than the Agricultural Education Research Farm whose soil type is more of sandy loam. This difference clearly shows the effectiveness of water retention of the clay loam than the sandy loam which make available water and nutrients for the use of the plants.

\section{Major Findings of the Study}

The study found out that:

- $\quad$ Cocoyam cultivation is viable and can be produced in large quantity in Kano State, Nigeria.

- Both species of cocoyam (Xanthosomasagitaifolium and Colocasiaesculenta performed better in terms of growth rate (height and leaf size) in the area of the study.

- Xanthosomasagitaifolium yielded high in terms of tuber at Watari Irrigation Scheme Site with fertilizer application as well as Colocasiaesculenta with organic manure application.

- With improved manuring and fertilizer application, cocoyam production in Kano State could be at par with that of the major producing areas.

\section{Conclusion}

The results of this study indicated that cocoyam can be effectively produced in Kano State. It can both be produced on irrigation scheme and any other available planting area. The study also concluded that Xanthosomasagitaifolium could yield better than Colocasiaesculenta. While fertilizer application yields higher, the combination of manure and fertilizer could produce better yield.

\section{Acknowledgements}

We acknowledged the financial support from the Tetfund grant under which this study was carried out. We also acknowledged the support of Research, Seminar and Publication Committee and some staff in the Department of Agricultural Education and Dr. Hussaini Y. Peni of Integrated Science Department FCE (T) Bichi for giving us the opportunity to use their experimental facilities and, technical assistance.

\section{References}

i. Abdulrahman S. AbdullahiA.and Muhammad B. (2015)Analysis of Constraints to Cocoyam Production in Kaduna State, Nigeria Journal of Scientific Research \& Reports6(3): XX-XX,2015; Article no.JSRR.2015.146www.sciencedomain.org

ii. Adamu, G.K (2013) An assessment of soil properties of watari irrigation project. Kano State, Nigeria. Academic Research International 4(4) pp 258. 
iii. Adelekan B. A. (2006), Principles and practices of irrigation: Institute of Agricultural Research and Training, Moor Plantation, Ibadan, Nigeria

iv. Amusa, T. A., Enete A.A. and U. E. Okon (2011) Socioeconomic determinants of cocoyam production among small holder farmers in Ekiti state, Nigeria; International Journal of Agricultural Economics \& Rural Development - 4 (2) IJAERD Press.

v. Chukwu G. O. (2015) Land Use for Cocoyam in Nigeria- Implications for Cocoyam Rebirth; Global Journal of Agricultural Research. Vol.3, No.2, pp.25-36

vi. Food and Agriculture Organization. (2014). Storage and processing of root and tubers in the tropics. Retrieved 4th January, 2014, from http://www.fao.org.

vii. Food and Agricultural organization (2006). Food Crop and Storage, Corporate Document Repository and Data base. Rome.

viii. International Institute for Tropical Agriculture (IITA, 2007). Growing cocoyam in Nigeria, commercial production guide series. Ibadan.

ix. Mare, R, Modi A.T (2009). Influence of planting date and organic fertilization on growth and yield of Taro landraces. African Crop Sci. Conf. Proc. 9:179-189.

x. Mary O. I, Dominic A. 0, and Cosmos O. M (2017) Growth and Yield Responses of Cocoyam (Colocasiaesculenta (L.) Schott) to Organic Wastes in the Humid Agro-Ecological Zone of South-Eastern, Nigeria. International Journal of Plant \& Soil Science16(6): 1-11.

xi. Ngene B. U., Jonah C. A., Imokhai T. T. and Gideon O. B. (2018) Geography of Udi Cuesta Contribution to HydroMeteorological Pattern of the South Eastern Nigeria

xii. Nenna M., Ugwumba C., Obiekwe J. and Akubuilo C. (2017) Strategies for Improving Cocoyam Production among Farmers in Anambra State, Nigeria: Discourse Journal of Agriculture and Food Sciences, Vol. 5(5): 60-65 www.resjournals.org/JAFS; ISSN: 2346-7002

xiii. Ogbonna P. E and Nweze N. J. (2012), Evaluation of growth and yield responses of cocoyam (Colocasiaesculenta) cultivars to rates of NPK 15:15:15fertilizer:African Journal of Agricultural Research Vol. 7(49), pp. 6553-6561 Available online at http://www.academicjournals.org/AJAR

xiv. Olaitan, S. O, Igbo, C. A, Nwachukwu, C. EOnyemachi, C.A and Ekong, A.O (1999). Curriculum Development and Management in Vocational Technical Education. Onitsha. Cape Publishers.

xv. Olaitan, S.O and Ali, A. (1997). The Making of Curriculum. Theory, Process, Product and Evaluation. Onitsha Cape Publishers Ltd.

xvi. Sangari, D U, (2006) An Evaluation of Water and Land Uses in the Kano River Project, Phase I, Kano State. Journal of Applied Sci. Environ. Management. Vol. 11 (2) 105 - 111 JASEM ISSN 1119-8362 www.bioline.org.b r/ja

xvii. Shanono, N.J.; A.A. Sabo; N.M. Nasidi; M.D. Zakari; M. Mohammed; H. Isma'il and A.G. Halilu (2015) Hydraulic Infrastructures and Institutional Assessment of Watari Irrigation Project, Kano State. Journal of Engineering and Technology (JET) Vol. 10 (2), 44- 51 www.bayerojet.com 44 and njshanono.age@buk.edu.ng

xviii. Smyder R.L, Melo J.P (2005) Frost protection: fundamental practice, and its economics; Environment and natural resources series 10 volume 1. Food and agriculture Organization of United Nations

xix. U.M. Dawaki, A.U. Dikko, S.S. Noma and U. Aliyu, (2013) Heavy Metals and Physicochemical Properties of Soils in Kano Urban Agricultural Lands.: Nigerian Journal of Basic and Applied Science, 21(3): 239-246; Available online ahttp://www.ajol.info/index.php/njbas/index

xx. Yau, S.L, Manasse, E.A and Sharifai, A. I (2014) Land evaluation for improved Rice Production in Watari Irrigation Project, Kano State, Nigeria. Bayero Journal of Pure and Applied Science. Vol.7(1) pp116-120. 